\title{
Short Communication: Molecular identification of White Sea Squirt Didemnum sp. (Tunicata, Ascidiacea) colonies growing over corals in Raja Ampat Islands, Indonesia
}

\author{
LUTHFI ANZANI ${ }^{1}$, HAWIS H. MADDUPPA ${ }^{1, \bullet}$, I WAYAN NURJAYA ${ }^{1}$, P. JOANA DIAS ${ }^{2}$ \\ ${ }^{1}$ Department of Marine Science and Technology, Faculty of Fisheries and Marine Science, Institut Pertanian Bogor. Jl. Raya Darmaga, Bogor 16680, \\ West Java, Indonesia. ”email: hawis@apps.ipb.ac.id \\ ${ }^{2}$ Department of Environment and Agriculture, Curtin University, Perth, WA, 6102, Australia
}

Manuscript received: 26 January 2018. Revision accepted: 10 February 2019.

\begin{abstract}
Anzani L, Madduppa HH, Nurjaya IW, Dias PJ. 2019. Short Communication: Molecular identification of White Sea Squirt Didemnum sp. (Tunicata, Ascidiacea) colonies growing over corals in Raja Ampat Islands, Indonesia. Biodiversitas 20: 636-642. Indonesia is at the center of the Coral Triangle, the region with the world's highest marine biodiversity. The Raja Ampat archipelago in east Indonesia has one of the oldest networks of marine protected areas in the country and is a top priority area for marine conservation. The area is however under anthropogenic pressure from growing tourism, developments and exploration of natural resources. The most likely associated introduction of non-native species is however largely unexplored. Colonial ascidians or 'sea squirts' comprise a high number of species, many of them reported as introduced or invasive worldwide. In this study, we investigate the presence of white colonial ascidian colonies noticed to overgrow sections of the coral reefs in central Raja Ampat. We use DNA barcoding to address the colonies' species identification and explore haplotype diversity to determine the species native or introduced status. We produced 22 DNA barcodes belonging to four potential cryptic Didemnum sp. species present in the Raja Ampat archipelago, Indonesia. Overall, the high number of haplotypes found in the area suggest these to most likely to be native species. The present work represents, as far as the authors are aware, the first time that such species were investigated in Raja Ampat. We hope with this work to create awareness for the topic of introduced and invasive species in the area and motivate further studies in Indonesia.
\end{abstract}

Keywords: DNA barcoding, coral triangle, mitochondrial, introduced species, native species, Biological invasion

\section{INTRODUCTION}

Indonesia sits firmly within the center of the Coral Triangle, the region with the world's highest marine biodiversity (Rosen 1988). Papua, the most eastern marine ecoregion in Indonesia, has been described as one of the areas with the highest diversity of coral and marine fish species in the world and is thus the country's top geographic priority for marine biodiversity conservation (Allen 2008). Like many other areas of Indonesia however, Raja Ampat is understudied for marine invertebrate species, as limited resources need to be prioritized and are often invested in the study of coral and fish species associated with fisheries (Huffard et al. 2012). Nevertheless, the sustainability of fisheries resources is highly dependent on the health of the underlying ecosystem, of which invertebrates (other than coral) are a major component. Over $90 \%$ of the population in Raja Ampat live in coastal areas and are dependent on marine resources for their livelihood (Kartikasari et al. 2012). Despite holding one of the oldest and most successfully managed Marine Protected Areas (MPAs) network in Indonesia, Raja Ampat has experienced an increase in tourism and economic development opportunities for the local communities. With the number of people, boats, and infrastructure increasing every year, the marine ecosystem in Raja Ampat, and especially the pristine abundant coral reefs, are increasingly under threat (Kartikasari et al. 2012; Atmodjo et al. 2018).

The increase in trade, travel, and transport worldwide has accelerated rates of introduction of marine invasive species through pathways such as shipping, aquaculture, and the aquarium trade (Hulme 2009). Introduced marine species are notoriously problematic worldwide as may be highly invasive or become so if conditions change. Invasive species can displace native species, modify habitats, affect community structure and ecosystem processes, impact human health and ultimately lead to substantial economic losses (Grosholz 2002; Madduppa et al. 2017). The impact of introduced species can be particularly devastating to high-value biodiversity regions like Raja Ampat (Baskin 2002), there is still an overwhelming lack of studies performed to address this issue in Indonesia (Kartikasari et al. 2012).

Identification and control of marine invasive species have been the focus of research and management worldwide in order to protect economic and ecological sectors dependent on the affected habitats (Naeem et al. 1994). Colonial ascidians or 'sea squirts' within the genus Didemnum (Tunicata, Ascidiacea) comprise a high number 
of species, many of them reported as introduced or invasive in various countries (Lambert 2002, Oliveira et al. 2017). They are abundant in many ports around the world and are generally characterized by a rapid growth rate, reaching sexual maturity in only a few weeks and producing planktonic larvae (Lambert 2002). The taxonomic identification of these species is however highly difficult, due to apparent high morphological similarity and small size of zooids, larvae, and spicules (Stefaniak et al. 2009). The lack of correct preservation techniques, inadequate sampling, and even the time at which sampling occurs (reproductive period) may obscure or eliminate important features, making it difficult to identify important morphological characters (Stefaniak et al. 2009, Dias et al. 2017). Identification of this taxonomic group has, however, in recent years, been successfully assisted by faster and accessible molecular identification techniques (Stefaniak et al. 2009). The mitochondrial DNA (mtDNA) cytochrome oxidase 1 (COI) barcode region is often the marker of choice when looking to identify and evaluate the genetic diversity of species, as it is widely available and usually exhibits high mutation rates leading to inter and intraspecific polymorphism (Hebert et al. 2003; Madduppa et al. 2014). The mtDNA COI barcode region has successfully been applied to numerous studies addressing species identification, phylogeography, and connectivity (Madduppa et al. 2014, 2016; Sembiring et al. 2014; Trivedi et al. 2016).
The team at the Marine Sciences Department of Bogor Agricultural University (IPB) conducts yearly coral reef surveys to the Raja Ampat archipelago, as part of national projects. During the survey conducted in 2016, the team noticed a white colonial ascidian overgrowing sections of the coral reefs and took the opportunity to collect opportunistic samples. The main objective of this study was to attempt to determine the colonies' species, using molecular (DNA barcoding) identification. By exploring species haplotype diversity and phylogenetics, we further aimed to determine if the observed species could be potentially assigned as native or introduced.

\section{MATERIALS AND METHODS}

\section{Sampling}

The team visited six sites in the Raja Ampat archipelago, namely Friwen, Mios Kon island, Arborek, Yenbuba Mansuar Island, Cape Kri Island and Akber Reef Kri Island. White colonial sea squirt colonies were observed growing over corals at four of the six sites (Figure 1). The Sampling was conducted in April 2016 by scuba divers between three to seven meters depth using the haphazard method (Hall et al. 2001). All samples were preserved in $96 \%$ ethanol and transported to the Marine Biodiversity and Biosystematics Laboratory at Bogor Agricultural University (IPB), Indonesia for processing.

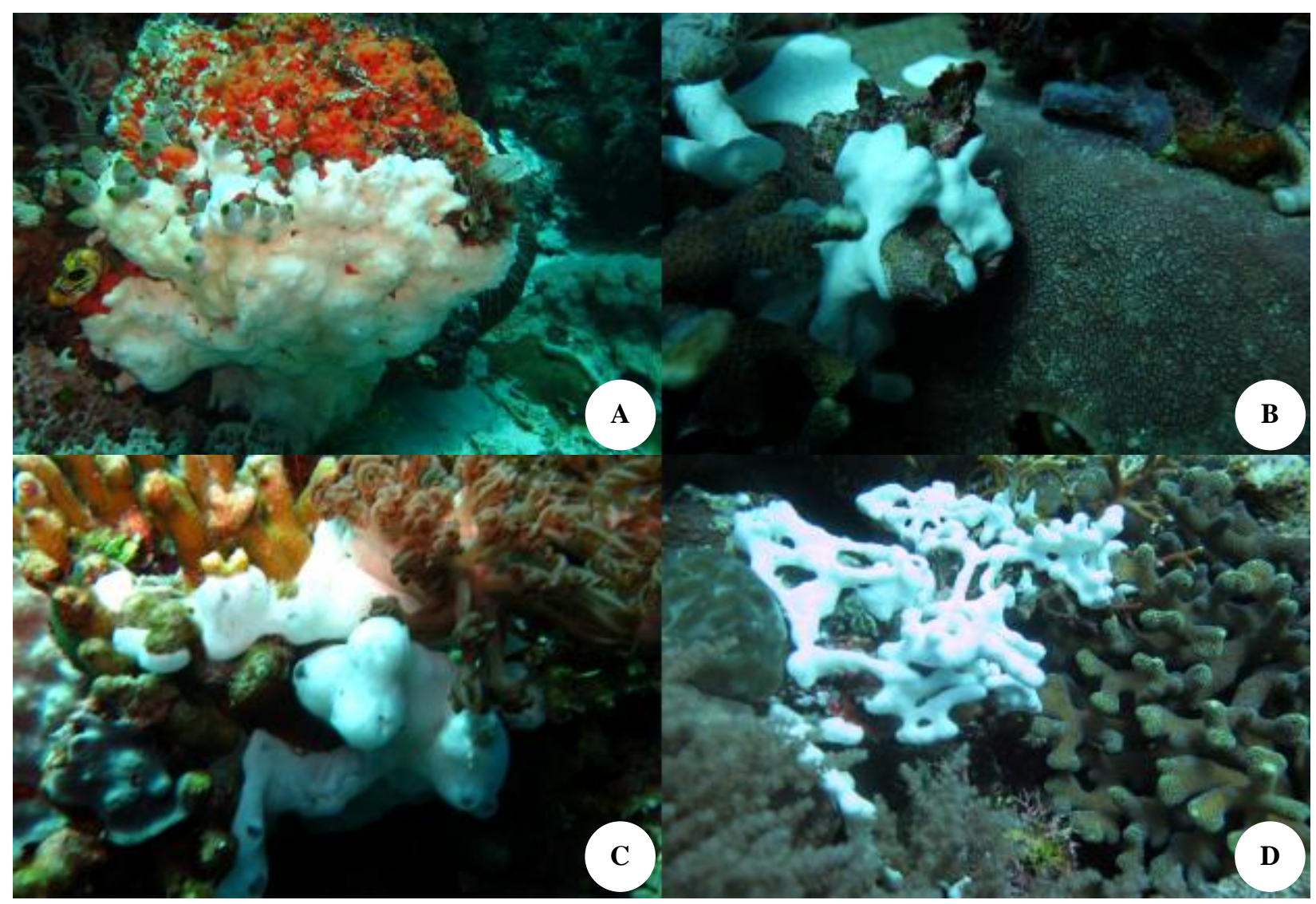

Figure 1. Photographs showing the overall aspect of the white sea squirt colonies sampled in Raja Ampat archipelago, Papua, Indonesia. A. Arborek, B. Yenbuba Mansuar Island, C. Akber Reef Kri Island, D. Cape Kri Island 


\section{DNA extraction, amplification, and sequencing}

A subsample of the colonial ascidian tissue (with tunic) was transferred to a microcentrifuge tube and DNA extracted using a Geneaid Tissue Genomic DNA Extraction Kit (Geneaid Biotech Ltd., New Taipei City, Taiwan), following the manufacturer's instructions. Polymerase Chain Reaction (PCR) amplification of the mtDNA COI gene region was performed using the LCO1490 and HCO2198 primers and conditions developed by Folmer et al. (1994) and the Tun_forward and Tun_reverse 2 primers and conditions developed by Stefaniak et al. (2009). PCR reactions were conducted in a peqStar 96 Universal (peqLab) thermal cycler. A negative control, with no template DNA added, was included in all PCR assays. PCR products were separated by electrophoresis using $1.5 \%$ agarose gels stained with ethidium bromide alongside a 100 base pairs (bp) molecular weight marker and visualized under UV light. Sequencing of unpurified PCR products was performed in one direction, using the BigDye ${ }^{\circledR}$ Terminator v3.1 cycle sequencing kit chemistry and analyzed on an ABI 3730 at First Base, Malaysia.

\section{Data analysis}

All sequences and the original chromatographs were manually checked for correct base calls and edited using the MEGA 6.0.5 (Molecular Evolutionary Genetic Analysis) program. Sequences were uploaded individually on the National Center for Biotechnology Information (NCBI) website and matched against the GeneBank database using the Basic Local Alignment Search Tool (BLAST). BLAST compares the uploaded sequences to all sequences on the GenBank databases and lists the closest significant matches (NCBI 2017).

Sequences were aligned and trimmed using MEGA 6.0.5 together with haplotypes of species' closest matches provided by BLAST and other worldwide introduced white colonial Didemnid species such as D. perlucidum. Analysis of genetic diversity was performed in DnaSP 4.0 (Rozas et al. 2003) and included the measurement of haplotype diversity (Hd) and nucleotide diversity $(\pi)$ (Nei 1987). Phylogenetic relationships were inferred using the Kimura 2-parameter method of the Neighbors-Joining (NJ) model and a bootstrap value of 1000x in Clustal W (Tamura et al. 2013). Trees were generated in MEGA 6.0.5. A mtDNA COI sequence of Diplosoma spongiforme (AY600972.1) was used as the base for evolutionary inference (outgroup). A haplotype network was generated using PopArt (Leigh and Bryant 2015).

\section{RESULTS AND DISCUSSION}

\section{DNA barcoding}

All attempts to amplify the COI barcode gene region with primers and conditions as per Folmer et al. (1994) failed. A total of 22 samples were successfully amplified and sequenced using the primers and conditions as per Stefaniak et al. (2009). The 22 white Didemnid colonies identified had their closest matches in GenBank for the species Didemnum vexillum, Didemnum psammatodes and Didemnum spadix (Table 1). We obtained 20 COI sequences 548 bp long, and two shorter sequences of 433 bp and $493 \mathrm{bp}$.

\section{Phylogenetic analysis, haplotype network and genetic diversity}

We identified 11 haplotypes, denoted H1-H11, namely Yenbuba Mansuar H1=2; Akber Reef Kri Island H2=4, H3=1; Cape Kri Island H2=2, H4=1, H5=3, H6=1, H10=1, $\mathrm{H} 11=1$; Arborek $\mathrm{H} 7=1, \mathrm{H} 8=3, \mathrm{H} 9=1, \mathrm{H} 10=1$ (Figure 2, Table 1). Phylogenetic analysis of the 22 Didemnum COI haplotypes revealed four well supported distinct clades, denoted clade 1-4 (Figure 3). The clear separation of these four COI clades was also apparent in a statistical parsimony haplotype network (Figure 4) with 22 hypothetical mutational steps separating the basal nodes of clade 1 and clade 2; 39 hypothetical mutational steps separating basal nodes of clade 2 to clade 3 ; and 66 hypothetical mutational steps separating the basal nodes of clade 3 and clade 4 (Figure 4).

Clade 1 included 8 sequences belonging to three haplotypes (H2, H9, H11) from three sampling sites: Arborek, Akber Reef Kri Island and Cape Kri Island. Clade 1 is represented by low genetic diversity, indicated by a low haplotype diversity value of 0.464 and nucleotide diversity of 0.036 . Clade 2 is represented by a single haplotype (H1) exclusively amplified from two samples collected at Yenbuba in Mansuar Island. Clade 3 is also represented by a single haplotype (H6) from a sample collected at Cape Kri Island and was the only sequence to have the closest match in GenBank to Didemnum spadix. Clade 4 consists of 11 samples represented by the most diverse haplotype group ( $\mathrm{H} 3, \mathrm{H} 4, \mathrm{H} 5, \mathrm{H} 7, \mathrm{H} 8, \mathrm{H} 10)$ and includes sequences from three sampling sites: Arborek, Akber Reef Kri Island, Cape Kri Island. Clade 4 shows a high genetic diversity, with a high haplotype diversity of 0.873 and nucleotide diversity of 0.079 . Estimates of genetic diversity were not performed for clades 2 and 3 due to the low number of samples (Table 1).

\section{Discussion}

In this study, we produced 22 DNA barcodes belonging to four potential cryptic Didemnum sp. species present in the Raja Ampat archipelago, Indonesia. Overall, the fact that different haplotypes were found in the area suggests these to most likely represent native species. The present work represents, as far as the authors are aware, the first time that such species were investigated in this top marine biodiversity and marine conservation priority area of Indonesia. We hope with this work to create awareness for the topic of introduced and invasive species in the area and motivate further studies in Indonesia. 
Table 1. NCBI Basic Local Alignment Search Tool (BLAST) result for white colonial Didemnid in Raja Ampat, Indonesia

\begin{tabular}{|c|c|c|c|c|c|c|c|}
\hline \multirow[b]{2}{*}{ ID } & \multirow[b]{2}{*}{ Sample Site } & \multirow[b]{2}{*}{ Haplotype } & \multirow[b]{2}{*}{ Clade } & \multicolumn{4}{|c|}{ BLAST } \\
\hline & & & & Species & Genebank ID & $\begin{array}{l}\text { Max } \\
\text { ident }\end{array}$ & $\begin{array}{l}\text { Query } \\
\text { Cover }\end{array}$ \\
\hline ITK_YNB_TUN_02 & Yenbuba & $\mathrm{H} 1$ & Clade 2 & Didemnum psammatodes & KU221189.1 & $89 \%$ & $100 \%$ \\
\hline ITK_YNB_TUN_03 & Mansuar & $\mathrm{H} 1$ & Clade 2 & Didemnum psammatodes & KU221189.1 & $89 \%$ & $100 \%$ \\
\hline ITK_AKB_TUN_05 & Akber Reef Kri & $\mathrm{H} 2$ & Clade 1 & Didemnum vexillum & KM259617.1 & $90 \%$ & $100 \%$ \\
\hline ITK_AKB_TUN_09 & Island & $\mathrm{H} 3$ & Clade 4 & Didemnum vexillum & EU742669.1 & $91 \%$ & $97 \%$ \\
\hline ITK_AKB_TUN_10 & & $\mathrm{H} 2$ & Clade 1 & Didemnum vexillum & KM259617.1 & $90 \%$ & $100 \%$ \\
\hline ITK_AKB_TUN_13 & & $\mathrm{H} 2$ & Clade 1 & Didemnum vexillum & KM259617.1 & $90 \%$ & $100 \%$ \\
\hline ITK_AKB_TUN_15 & & $\mathrm{H} 2$ & Clade 1 & Didemnum vexillum & KM259617.1 & $90 \%$ & $100 \%$ \\
\hline ITK_CPE_TUN_04 & Cape Kri Island & H11 & Clade 1 & Didemnum psammatodes & KU221189.1 & $90 \%$ & $100 \%$ \\
\hline ITK_CPE_TUN_05 & & $\mathrm{H} 10$ & Clade 4 & Didemnum vexillum & JQ663515.1 & $90 \%$ & $100 \%$ \\
\hline ITK_CPE_TUN_07 & & H4 & Clade 4 & Didemnum vexillum & JQ663515.1 & $90 \%$ & $100 \%$ \\
\hline ITK_CPE_TUN_08 & & H5 & Clade 4 & Didemnum vexillum & EU742669.1 & $91 \%$ & $97 \%$ \\
\hline ITK_CPE_TUN_12 & & $\mathrm{H} 5$ & Clade 4 & Didemnum vexillum & EU742669.1 & $91 \%$ & $97 \%$ \\
\hline ITK_CPE_TUN_17 & & $\mathrm{H} 2$ & Clade 1 & Didemnum vexillum & KM259617.1 & $90 \%$ & $100 \%$ \\
\hline ITK_CPE_TUN_18 & & H5 & Clade 4 & Didemnum vexillum & EU742669.1 & $91 \%$ & $97 \%$ \\
\hline ITK_CPE_TUN_21 & & $\mathrm{H} 2$ & Clade 1 & Didemnum vexillum & KM259617.1 & $90 \%$ & $100 \%$ \\
\hline ITK_CPE_TUN_22 & & H6 & Clade 3 & Didemnum spadix & KU667267.1 & $94 \%$ & $79 \%$ \\
\hline ITK_ARB_TUN_02 & Arborek & H7 & Clade 4 & Didemnum vexillum & JF738068.1 & $91 \%$ & $97 \%$ \\
\hline ITK_ARB_TUN_03 & & $\mathrm{H} 8$ & Clade 4 & Didemnum vexillum & EU742669.1 & $91 \%$ & $97 \%$ \\
\hline ITK_ARB_TUN_04 & & H8 & Clade 4 & Didemnum vexillum & EU742669.1 & $91 \%$ & $97 \%$ \\
\hline ITK_ARB_TUN_05 & & H8 & Clade 4 & Didemnum vexillum & EU742669.1 & $91 \%$ & $97 \%$ \\
\hline ITK_ARB_TUN_06 & & $\mathrm{H} 10$ & Clade 4 & Didemnum vexillum & JQ663515.1 & $90 \%$ & $100 \%$ \\
\hline ITK_ARB_TUN_14 & & H9 & Clade 1 & Didemnum psammatodes & KU221189.1 & $90 \%$ & $100 \%$ \\
\hline
\end{tabular}

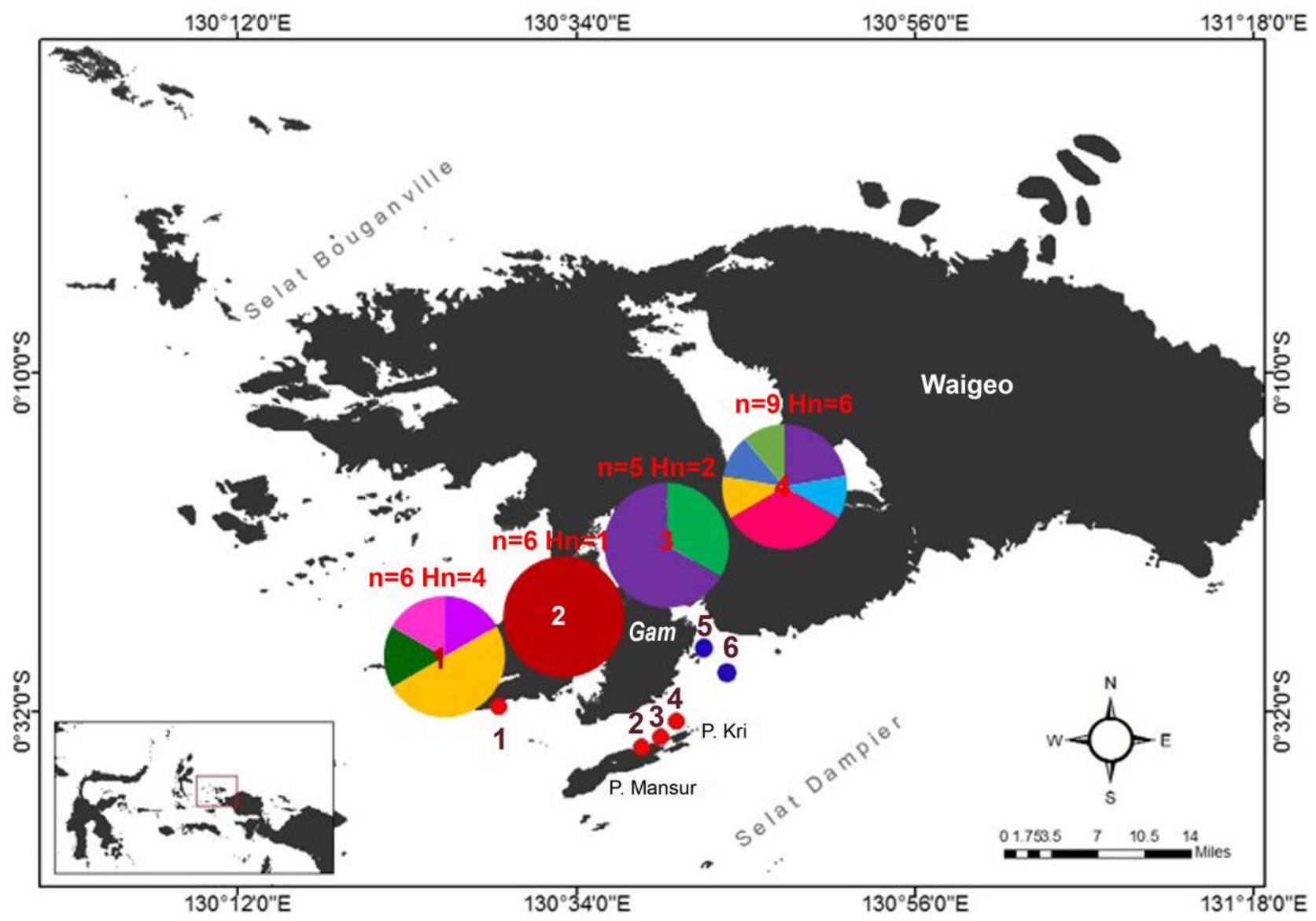

Figure 2. Map showing sampling sites in Raja Ampat: (1) Arborek, (2) Yenbuba Mansuar Island, (3) Akber Reef Kri Island and (4) Cape Kri Island (5) Friwen, (6) Mios Kon island. Number of (n) white Didemnid colonies sequenced and haplotypes (Hn) observed per site are shown above pie charts indicating the different haplotypes (different colors) found per site 


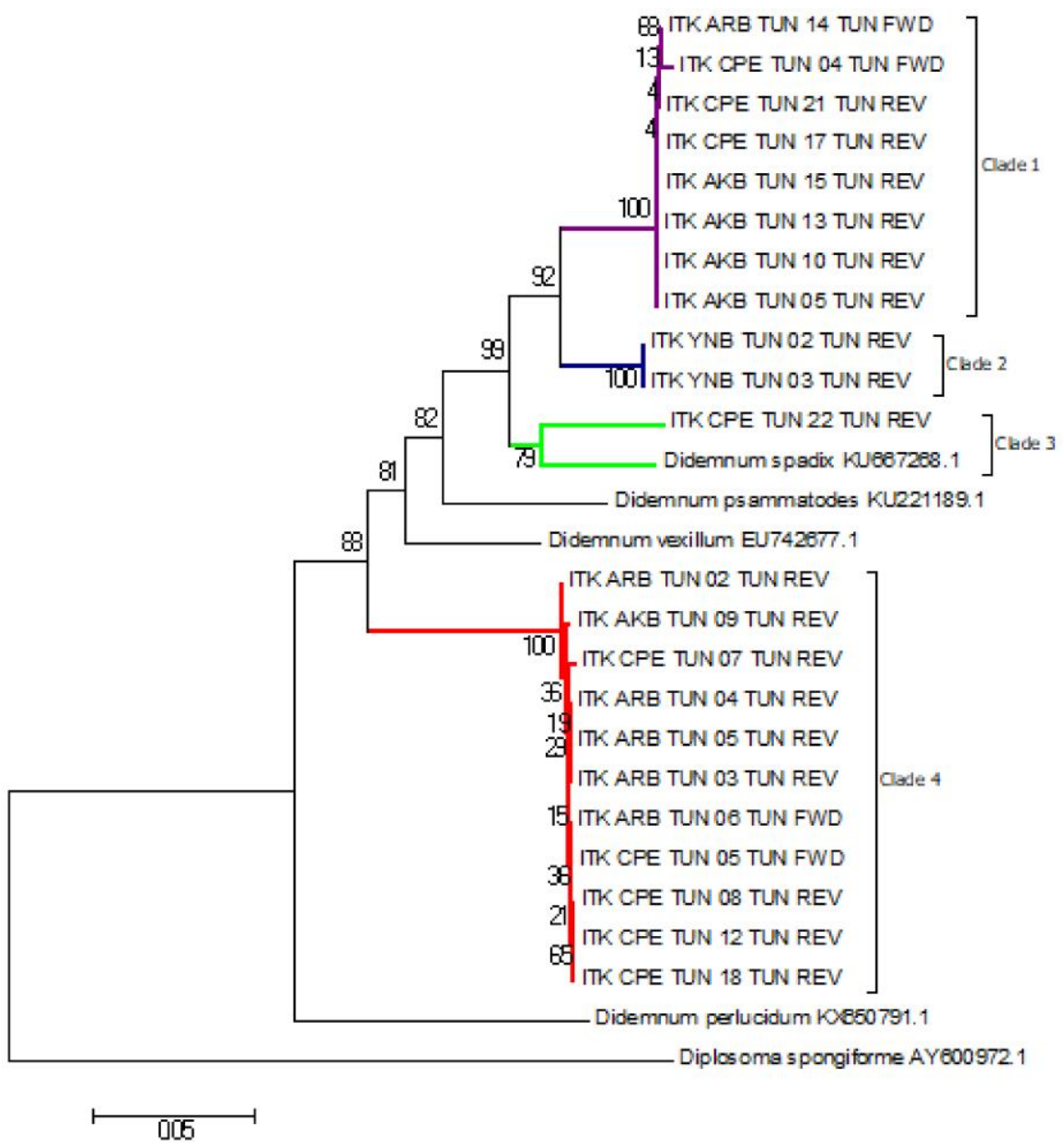

Figure 3. Phylogenetic Neighbors-Joining (NJ) reconstruction of haplotypes of Didemnum sp. colonies collected in the Raja Ampat archipelago, Indonesia. The tree is drawn to scale and rooted on Diplosoma spongiformis. The four main clade groupings are indicated on the right of the tree in colors corresponding to clades identified in the haplotype network (Figure 3). Details on all sequences can be found in Table 1 .
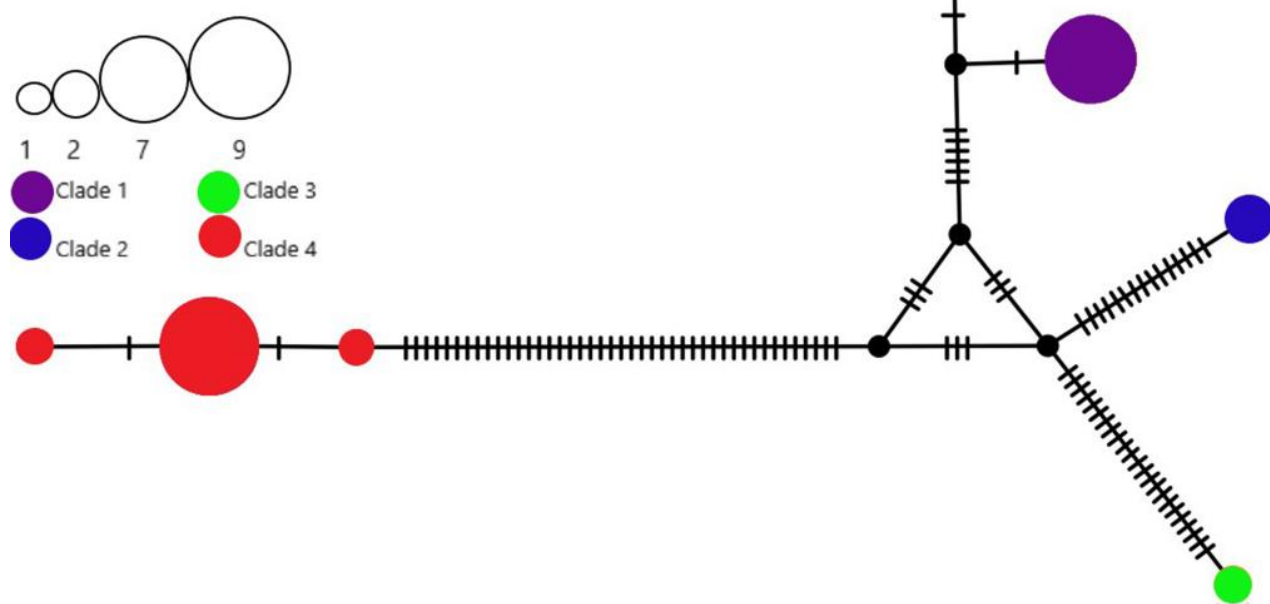

Figure 4. Relationship among haplotypes from COI of Didemnum sp. colonies collected in the Raja Ampat archipelago, Indonesia. For more details on sampling locations see Figure 1. The size of the circle corresponds to the frequency of haplotypes over all samples. Circles are color coded by clades corresponding to the tree in Figure 2. 


\section{Species identification}

In this study, while none of the collected samples were able to be amplified using the Folmer et al. 1994 primers, using the more specifically developed Stefaniak et al. 2009 primers we were able to obtain an overall DNA barcoding success of $46 \%$. Similar molecular identification studies have reported the difficulty in amplifying the high diversity of ascidian species sampled worldwide (Stefaniak et al. 2009). This is likely due to the acknowledged high diversity of ascidian species, largely undescribed, and a high number of ascidian species for which DNA barcodes are still lacking in databases such as Genbank (Stefaniak et al. 2009; Oliveira et al. 2017).

The closest matches obtained using the NCBI BLAST suggest that the samples collected belong most likely to species within the genus Didemnum (identity 89-91\%, Table 1) that have not previously been barcoded. The GenBank nucleotide database contains more than one hundred million sequences representing more than 275,000 species. However, these represent only 3\% of Earth's species (Hebert et al. 2003, Hinhcliff and Smith 2014). Raja Ampat is considered to have some of the highest marine biodiversity in the world and research on speciose invertebrate groups remains challenging, with many new species to be described. Nevertheless, the DNA barcoding of Didemnum sp. in Raja Ampat represents new data for this region. While only detailed taxonomic research can assign the DNA barcodes to previously described or undescribed sea squirt species, molecular analysis like the present one can be used as a quick screening method for identification against the most notorious invasive Didemnids such as $D$. perlucidum and $D$. vexillum. They can also represent the beginning of DNA barcoding libraries, that can be built relatively faster and prove a useful alternative for building important baseline invertebrate biodiversity surveys.

\section{Species origin: native or introduced?}

Colonial sea squirts are opportunistic species that tend to occupy available space on reefs and are often observed over areas where coral was previously killed (e.g., bleaching, storms). The fact that this was not the case in the four sites where the colonies were observed raises suspicion about the introduced status and invasive potential. The colonies were noticed overgrowing healthy reef areas. Although colonies formed relatively small mats, they were patchy over larger areas. Nevertheless, the colonies coverage area was not massive as it is known from notorious invasive species such as Didemnum vexillum (McKenzie et al. 2017). They were also only found at 4 of the 6 sites visited, suggesting that the species, or their behavior, is not widely spread.

The phylogenetic analysis and haplotype network suggest the DNA barcodes belong to four distinct haplotype groups, representative of potentially four distinct cryptic species. Overall the haplotype diversity found suggests the samples to most likely originate from native species. The fact that we did not found high haplotype diversity at sites like YNB could be a sampling artifact resulting from the low number of samples collected and the $46 \%$ DNA barcoding success. With the exception of YNB, all other sites share haplotypes, indicating there is some connectivity between sites. Larvae of Didemnum are nonfeeding larvae that can swim for up to two hours before settling on a new substrate (Lengyel et al. 2009, Mercer et al. 2009). Although this can be considered a relatively short planktonic time, if the currents are strong enough, they can justify the observed overlapping of haplotypes between Arborek and Kri Island in central Raja Ampat.

Many sea squirt species, namely within the genus Didemnum, have become widespread introduced and invasive species around the world's marine waters. However, generally their introduced status is represented by extremely low haplotype diversity in the invaded region (Rocha et al. 2012, Stefaniak et al. 2012). This is overall not the case in this study, and therefore it can be presumed that these species are most likely native in Raja Ampat. Further research would be needed to confirm this that could include studies looking at invertebrate species present in harbors and anchorages, in order to investigate the susceptibility of its pristine coral reefs to potential invaders. In this sense, awareness, education and baselines surveys can prove most useful for the long-term conservation of this remarkable marine paradise (Scott et al. 2017).

\section{ACKNOWLEDGMENTS}

This paper is supported by USAID through Sustainable Higher Education Research Alliances (SHERA) ProgramAnimal Biotechnology and Coral Reef Fisheries (ANBIOCORE). This study was funded by Kementerian Riset Teknologi dan Pendidikan Tinggi (Ristekdikti) in the scheme "Kerjasama Luar Negeri dan Publikasi Internasional" (Contract no. 1415/IT3.11/PN/2017). This study was supported by Marine Biodiversity and Biosystematics Laboratory, Department of Marine Science and Technology, Bogor Agricultural University, Bogor, West Java, Indonesia. The authors would like to thank Miss Nurlita Putri Anggraeni for technical laboratory support.

\section{REFERENCES}

Allen GR. 2008. Conservation hotspots of biodiversity and endemism for Indo-Pacific coral reef fishes. Aquatic Conserv: Mar. Freshw. Ecosyst 18: 541-556. DOI: $10.1002 / \mathrm{aqc} .880$

Atmojo E, Lamers M, Arthur P (2018) Financing marine conservation tourism: Governing entrance fees in Raja Ampat, Indonesia. Mar Pol 78: 181-188.

Baskin Y. 2002. A Plague of Rats dan Rubber-Vines: The Growing Threat of Species Invasions. Island Press, Washington, D.C

Dias PJ, Fotedar S, Munoz J, Hewitt MJ, Lukehurst S, Hourston M, Wellington C, Duggan R, Bridgwood S, Massam M, Aitken Vi, Lestang PD, Mckirdy S, Willan R, Kirkendale L, Giannetta J, Corsini-Foka M, Pothoven S, Gower F, Viard F, Buschbaum C, Scarcella G, Strafella P, Bishop MJ, Sullivan T, Buttino I, Madduppa H, Huhn M, Zabin CJ, Bacela-Spychalska K, Wójcik-Fudalewska D, Markert A, Maximov A, Kautsky L, Jaspers C, Kotta J, Pärnoja M, Robledo D, Tsiamis K, Küpper FC, Žuljević A, Mcdonald JI, Snow M. 2017. Establishment of a taxonomic and molecular reference 
collection to support the identification of species regulated by the Western Australian Prevention List for Introduced Marine Pests. Manag Biol Invas 8 (2): 215-225.

Folmer O, Black M, Hoeh W, Lutz R, Vrijenhoek R. 1994. DNA primers for amplification of mitochondrial cytochrome $\mathrm{c}$ oxidase subunit I from diverse metazoan invertebrates. Mol Mar Biol Biotech 3: 294299.

Grosholz E. 2002. Ecological and evolutionary consequences of coastal invasions. Trends Ecol Evol 17: 22-27. DOI: 10.1016/S0169-5347 (01)02358-8

Hall T, Herron T, Pierce B, Witt T. 2001. The effectiveness of increasing sample size to mitigate the influence of population charachteristic in haphazard sampling. Auditing J Pract Theor 20 (1): 169-185.

Hebert PDN, Cywinska A, Ball SL, deWaard JR. 2003. Biological identifications through DNA barcodes. Proc R Soc London B 270 313-321.

Hinchliff CE, Smith SA. 2014. Some limitations of public sequence data for phylogenetic inference (in Plants). PLoS One 9 (7): e98986. DOI: 10.1371/journal.pone.0098986.

Huffard CL, Erdmann MV, Gunawan TRP (eds). 2012. Geographic Priorities for Marine Biodiversity Conservation in Indonesia. Ministry of Marine Affairs and Fisheries and Marine Protected Areas Governance Program, Jakarta, Indonesia.

Hulme PE. 2009. Trade, transport and trouble: managing invasive species pathways in an era of globalization. J Appl Ecol 46: 10-18.

Kartikasari SN, Marshall AJ, Beehler BM. 2012. Ekologi Papua. Yayasan Pustaka Obor Indonesia dan Conservation International, Jakarta. [Indonesian]

Lambert G. 2002. Nonindigenous Ascidian in Tropical Waters. Pacific Sci 56 (3): 291-298.

Leigh JW, Bryant D. 2015. popart: full-feature software for haplotype network construction. Methods Ecol Evol 6: 1110-1116. DOI: 10.1111/2041-210X.12410.

Madduppa H, Ayuningtyas RU, Subhan B, Arafat D, Prehadi. 2016 Exploited but unevaluated: DNA Barcoding reveals skates and stingrays (Chordata, Chondrichthyes) species landed in the Indonesian fish market. Ilmu Kelautan (IJMS) 21 (2): 77-84.

Madduppa H, Schupp PJ, Faisal MR, Sastria MY, Thoms C. 2017. Persistent outbreaks of the "black disease" sponge Terpios hoshinota in Indonesian coral reefs. Mar Biodiv 47: 149. DOI: 10.1007/s12526 015-0426-5

Madduppa H, Timm J, Kochzius M. 2014. Interspecific, spatial and temporal variability of self-recruitment in anemone fishes. PLoS One. 9: e90648. DOI: 10.1371/journal.pone.0090648

McKenzie, C. H, Reid, V, Lambert, G, Matheson, K, Minchin, D, Pederson, J, Brown, L. et al. 2017. Alien species alert: Didemnum vexillum Kott, 2002: Invasion, impact, and control. ICES Cooperative Research Report No. 335.33pp

Naeem S, Thompson LJ, Lawer SP, Lawton JH, Woodfin RM. 1994. Declining biodiversity can alter the performance of ecosystems. Nature 368: 734-737. DOI: 10.1038/368734a0.

NCBI Resource Coordinators. 2017. Database Resources of the National Center for Biotechnology Information. Nucleic Acids Res 45 (Database issue): D12-D17. DOI: 10.1093/nar/gkw1071.

Oliveira FAS, Michonneau F, Lotufo TMC. 2017. Molecular phylogeny of Didemnidae (Ascidiacea: Tunicata). Zool J Linn Soc 180: 603-612.

Rocha DRM, Kremer LP, Fehlauer-Ale KH. 2012. Lack of COI variation for Clavelina oblonga (Tunicata, Ascidiacea) in Brazil: Evidence for its human-mediated transportation? Aquat Invas 7 (3): 419-424.

Rosen BR. 1988. Progress, problems and patterns in the biogeography of reef corals and other tropical marine organisms. Helgoländer Meeresuntersuchungen 42: 269-301.

Rozas JJ, Sanchez DBC, Messequer X, Rozas R. 2003. DnaSP. DNA polymorphism analyses by the coalescent and other methods. Bioinformatics 19: 2496-2497.

Scott JK, McKirdy SJ, van der Merwe J, Green R, Burbidge AA, Pickles G, Hardie DC, Morris K, Kendrick PG, Thomas ML, Horton KL, O'Connor SM, Downs J, Stoklosa R, Lagdon R, Marks B, Nairn M, Mengersen K. 2017. Zero-tolerance biosecurity protects highconservation-value island nature reserve. Sci Rep 7: 772.

Sembiring A, Pertiwi NPD, Mahardini A, Wulandari R, Kurniasih EM, Kuncoro AW, Cahyani NKD, Anggoro AW, Ulfa M, Madduppa H, Carpenter KE, Barber PH, Mahardika GN. 2014. DNA Barcoding reveals targeted fisheries for endangered sharks in Indonesia. Fisher Res 164: 130-134. DOI: 10.1016/j.fishres.2014.11.003 0165-7836

Stefaniak L, Lambert G, Gittenberger A, Zhang H, Lin S, Whitlatch RB. 2009. Genetic conspecificity of the worldwide populations of Didemnum vexillum Kott, 2002. Aquat Invas 4 (1): 29-44.

Stefaniak L, Zhang H, Gittenberger A, Smith K, Holsinger K, Lin S, Whitlatch RB. 2012. Determining the native region of the putatively invasive ascidian Didemnum vexillum Kott, 2002. J Exp Mar Biol Ecol 422: 64-71.

Tamura K, Peterson D, Peterson N, Stecher G, Nei M, Kumar S. 2013. MEGA5: Molecular evolutionary genetics analysis using Maximum Likelihood. evolutionary distance. and maximum parsimony methods. Mol Biol Evol 28 (10): 731-739.

Willette DA, Allendorf FW, Barber PH, Barshis DJ, Carpenter KE, Crandall ED, Cresko WA, Fernandez-Silva I, Matz MV, Meyer E, Santos MD, Seeb LW, Seeb JE. 2014. So, you want to use nextgeneration sequencing in marine systems? Insight from the PanPacific Advanced Studies Institute. Bull Mar Sci 90 (1): 79-12. 